University of Wollongong

Research Online

Faculty of Law, Humanities and the Arts Papers (Archive)

$1-1-2019$

Boycott them! No, boycott this! Do choice overload and small-agent rationalization inhibit the signing of anti-consumption petitions?

Ulku Yuksel

University of Sydney

Nguyen T. Thai

University of Wollongong, nthai@uow.edu.au

Michael S. Lee

University of Auckland, msw.lee@auckland.ac.nz

Follow this and additional works at: https://ro.uow.edu.au/lhapapers

Part of the Arts and Humanities Commons, and the Law Commons

Research Online is the open access institutional repository for the University of Wollongong. For further information contact the UOW Library: research-pubs@uow.edu.au 


\title{
Boycott them! No, boycott this! Do choice overload and small-agent rationalization inhibit the signing of anti-consumption petitions?
}

\author{
Abstract \\ The Internet and social media have increased the number of organizations and individuals asking \\ consumers to sign petitions against transgressing brands. This raises a question as to whether such \\ increases in requests to sign a petition to support a boycott positively or negatively impact on consumer \\ willingness to enact anti-consumption. Via experiments, this study investigates the effect that choice \\ overload has on consumers signing a petition in support of a boycott call. The findings establish that \\ individuals who need to make a choice from numerous boycott calls (i.e., large choice-sets) are less likely \\ to sign a petition to support a boycott than individuals making a similar choice from a small number of \\ boycott calls (i.e., small choice-sets). The study further introduces a mediator that explains this effect. \\ Compared with individuals facing a small choice-set, those facing numerous options are more likely to \\ experience the small-agent rationalization, and thus, are less likely to sign the petition to support a \\ boycott. The small-agent rationalization (SAR) relates to one's acceptance of inequity in the world as well \\ as perceptions of their own powerlessness. The study establishes the role of choice overload in boycott \\ literature and empirically tests SAR as the process mechanism. Theoretical, practical, and policy \\ implications are discussed.

\section{Disciplines} \\ Arts and Humanities | Law

\section{Publication Details} \\ Yuksel, U., Thai, N. T. \& Lee, M. S. W. (2019). Boycott them! No, boycott this! Do choice overload and \\ small-agent rationalization inhibit the signing of anti-consumption petitions?. Psychology of Marketing, \\ Online First 1-15.
}




\title{
Boycott them! No, boycott this! Do choice overload and small-agent rationalization inhibit the signing of anti-consumption petitions?
}

\begin{abstract}
The Internet and social media have increased the number of organizations and individuals asking consumers to sign petitions against transgressing brands. This raises a question as to whether such increases in requests to sign a petition to support a boycott positively or negatively impact on consumer willingness to enact anti-consumption. Via experiments, this study investigates the effect that choice overload has on consumers signing a petition in support of a boycott call. The findings establish that individuals who need to make a choice from numerous boycott calls (i.e., large choice-sets) are less likely to sign a petition to support a boycott than individuals making a similar choice from a small number of boycott calls (i.e., small choice-sets). The study further introduces a mediator that explains this effect. Compared with individuals facing a small choice-set, those facing numerous options are more likely to experience the small-agent rationalization, and thus, are less likely to sign the petition to support a boycott. The small-agent rationalization relates to one's acceptance of inequity in the world as well as perceptions of their own powerlessness. The study establishes the role of choice overload in boycott literature and empirically tests smallagent rationalization as the process mechanism. Theoretical, practical, and policy implications are discussed.
\end{abstract}

Key words - choice overload, boycott, small-agent rationalization, petition, anticonsumption, powerlessness, inequity, sign a petition 


\section{Introduction}

In 2014, a journalist from Delhi was shocked at the rape of a 25 -year-old woman by an Uber driver, so she started a petition on Change.org demanding the company mandate a 7year background check of all drivers in India as it does in the US (Change.org, 2016). The petition was successful with 63,593 supporters (Change.org, n.d.-a). As a response, Uber made prompt changes prioritizing and committing to the safety of their customers by employing background checks, document verification, and police re-verification.

The above example is one of many successful stories about consumer activists using petition sites like Change.org to challenge firms, organizations, and even governments. A browse on the Internet and a visit to various social media outlets reveal numerous calls for boycotts or petition requests against transgressive brands. Indeed, copious requests to support boycott calls appear in people's Facebook newsfeed every day. Thanks to social media, thousands of people or groups look for online support of their calls, and thousands of people sign these petitions, which they then share on social media. Activists utilize technology for social change, and e-petitions offer great potential. E-petitions are widely used with hundreds of thousands of online petitions created worldwide each year with millions of signatures supporting various causes (Wright, 2016), thanks to websites such as Change.org that provide free platforms hosting campaigns with the mission of "empower[ing] people everywhere to create change they want to see," claiming to have over 240 million passionate members (Change.org, n.d.-b). Popular topics of e-petitions range from issues of human rights, economics, education, health, and sustainable food, to criminal justice, animal rights, and environmental protection. The phenomenon of e-petitions that are interactive and involving public mobilization and collective actions via cooperation with others (Sheppard, 2015), sometimes generated by new social ties, can be referred to as ethical consumption empowerment (Forno \& Graziano, 2014). The augmentation of individual consumption or 
anti-consumption decisions of ethical consumers give rise to social change, created collectively as an outcome of consumer empowerment in the marketplace (Papaoikonomou \& Alarcón, 2017).

Requests for "signing a petition" to support a boycott call are very common for consumers on social media. Whilst such demands are increasingly popping up in many online, digital, and interactive environments, we wonder whether the increasing number of announcements might decrease their effectiveness. Research confirms that providing consumers with too many product offerings causes choice overload effects in the retail environment (e.g., see Chernev, Böckenholt, \& Goodman, 2015 for a discussion; Lee \& Lee, 2004). Accordingly, we argue in this current research that similar overload effects may be experienced with increased demand for signing e-petitions. Therefore, it is reasonable to expect that the same negative effects of choice overload may also emerge when consumers need to select a transgressive brand to boycott in an online environment.

Signing an online petition to support a boycott against a transgressive brand may be less taxing for consumers than partaking in actual boycotts organized by boycott organizers. Even though cost of boycotting is a predictor of boycott participation (Sen, Gürhan-Canli, \& Morwitz, 2001), asking customers to sign an e-petition remains important for two reasons. First, even when consumers do not actually boycott, by simply signing a petition they show their support, and thus, provide word-of-mouth about the significance of the boycott case (Hennig-Thurau, Gwinner, Walsh, \& Gremler, 2004). Such support is important to increase boycott participation. Second, consumers who publicly announce that they support a boycott will be more likely to follow their promise and participate in the actual boycott (Garrett, 1987). Although online actions such as signing a petition may help people feel good about themselves; thus, potentially, decreasing the need for further actions with tangible impacts (Morozov, 2012; Skoric, 2012), there is still evidence that these low-effort acts encourage 
further-involved actions (e.g., volunteering, engaging in conscious consumption, and donation; Lee \& Hsieh, 2013) as well as traditional activist behaviors such as participating in social movements (Parigi \& Gong, 2014). Clearly, social-networking sites and communication tools (e.g., Facebook or Twitter) allow individuals to connect to each other easily, encouraging them to make significant impacts collectively in these online spaces (Resnick, 2002; Shirky, 2011). Although calls for online audiences to sign petitions in support of a boycott have become very popular with the rise in social media usage; anticonsumption research has not yet introduced this important tool (as an outcome variable) to boycott studies. Given that signing petitions may increase boycott participation, and thus, the chances of boycott success, it is worthwhile to introduce "petition signing" as a new way to measure boycott likelihood, and thus, allow anti-consumption scholars to benefit from the strength of this popular method of protest.

We argue that numerous "sign a petition" requests on social media may create similar choice overload effects as being exposed to too many products. Accordingly, we explore the effect of choice overload on consumers signing a petition in support of a boycott.

Contributing to both boycott and choice overload literature, this study is the first to introduce the notion that many requests to sign a boycott petition against transgressive brands may inhibit anti-consumption. Importantly, this study establishes the construct of "small-agent rationalization" (SAR) via a scale, which enhances our understanding of the underlying mechanism that explains the effect of large choice-sets on consumers' likelihood to support boycotts.

Prior literature already supports the idea that individuals perceive themselves as "small" when they confront a large firm, which makes them assess an individual act of protest as personally costly (Klein, Smith, \& John, 2004). This present research further proposes that SAR is a thought process that occurs when people begin accepting inequity in 
the world as a common occurrence, and that they alone at the "micro-level" are incapable of enacting change within a "macro-level" system (such as a globalized marketplace). The study then discusses the components of SAR and provide empirical evidence for its effect. Finally, the study concludes with managerial and policy implications based on research findings.

\section{Boycott calls, petition signing, and exposure to many choices}

Consumer protests against companies and brands comprise several attitudes and actions, ranging from opposition, such as boycotts, to supporting, such as buycotts (Ettenson, Smith, Klein, \& John, 2006; Hoffmann, Balderjahn, Seegebarth, Mai, \& Peyer, 2018) and carrotmobs (Hoffmann \& Hutter, 2012). With the ubiquitous presence of the Internet and social media, consumers are increasingly asked to participate in protests, requiring them to sign petitions against transgressing organizations. Such requests require them not only to complain about the company to wider audiences but also sometimes publicly announce a boycott promise against transgressive brands. The term transgressive brand refers to a brand that violates its relationship with its consumers and breaches some important (clear or subtle) norms (Aaker, Fournier, \& Brasel, 2004; Humphreys \& Thompson, 2014).

Boycotts are conditional acts of anti-consumption (Yuksel, 2013; Yuksel \& Mryteza, 2009) where consumers depart from a relationship with an organization or a transgressive brand that they disapprove of, due to some form of misconduct. Boycott practice involves stopping or limiting consumption with the transgressing company or brand (Friedman, 1999; Yuksel \& Mryteza, 2009). However, unlike some acts of anti-consumption, which may be incurable (Lee, Motion, \& Conroy, 2009), boycotts provide an assurance of relationship rebuilding once some specified conditions have been met by the company (Hirschman, 1970).

A petition is a document signed by numerous people, announcing a demand that requires a corporation or public entity to take action to remedy a transgression. Petitions 
signed online have become common practice, used in combination with social media, which lead targeted consumers to the petition website (Antonetti \& Manika, 2017). Online petitions or e-petitions, which usually focus on a single issue or goal, have increased participation of citizens who have previously been inattentive in protesting company actions or government policies that they disapprove (Sheppard, 2015). Evidently, e-petitions owe their popularity to the recent emergence of online petition websites, such as Change.org, which asks their targets to start a petition every day.

When consumers are exposed to many products or services they may experience negative choice overload effects, leading to regret, dissatisfaction, deferring a choice, and/or rejecting choice altogether, which may even result in no purchases being made (Chernev et al., 2015; Thai \& Yuksel, 2017). This is because when faced with numerous options, consumers need to make trade-offs or comparisons among alternatives, which may all be equally attractive. Thus, a choice process involving many options is sometimes harder and more agonizing, resulting in greater conflict than a decision involving only a few options (Xu, Jiang, \& Dhar, 2013). One of the most important reasons of such frustration may be the fact that consumers equally like the majority of options available and/or find alternatives so similar to each other that they feel unable to select the best option.

Likewise, we argue that individuals who are exposed to many boycott calls (all asking for their signatures to not only show support for the petition but also, in most cases, to enact a boycott) may also feel similarly overwhelmed, given that most of the issues presented may seem equally important and worth supporting. But, individuals have a restricted amount of physical, cognitive, and emotional resources (Drolet \& Luce, 2004). Thus, the cost of acting on all or many of those similarly important calls may seem so high that it becomes impossible to act upon all the boycott calls. Thus, individuals called for boycotting may perceive the pressure to select one or just a few calls to support. The necessity to choose one 
or only a few calls out of many is where the choice overload effect becomes salient. An environment with abundant choices, together with an inevitable pressure to select one or two calls, may prevent potential supporters from making any choice, as they cannot equitably decide which call to support. Thus, individuals presented with numerous significant boycott calls may be reluctant to do so, and thus, may end up signing no petition. In contrast, being exposed to a limited amount of boycott calls that require support may enhance choicemaking, since, in such cases, individuals have more temporal and cognitive resources, face fewer personal costs, and thus, may find it easier to make decisions. Thus,

$\mathbf{H}_{1}$ : Individuals exposed to many boycott calls are less likely to sign a petition to support a boycott than individuals exposed to a few boycott calls.

\section{Small-agent rationalization}

Factors predicting boycott participation include one's desire to make a difference, need for self-enhancement, perceived effectiveness of the boycott (John \& Klein, 2003), the cost of the boycott to the boycotter caused by restricted consumption, and finally, several consumer counterarguments (Hoffmann, 2013; Klein et al., 2004; Lasarov, Mai, de Frutos, Egea, \& Hoffmann, 2019; Yuksel, 2013). Counterarguments may stem from doubts about the existence or exaggeration of the accusation itself or its effects (Yuksel, 2013), which may reflect biased assimilations provoked by the media, politics, and so forth (Ahluwalia, 2000), or from doubts about the calling party, or the individual's denial for being responsible to act upon the accusation and their effects (Thompson \& Barton, 1994).

Counterarguments may be initiated by non-participants to rationalize their in-action (Hoffmann, 2013; Klein et al., 2004; Yuksel, 2013). When the boycott call is perceived as valid and legitimate but requires high sacrifices or is hard to follow, consumers usually strive to find some reasonable counterarguments so that they can reduce the extent to which they 
feel guilty or obliged (Lasarov et al., 2019) to boycott, particularly if they feel boycotting to be the ethical action to conduct. Such counterarguments fall into the category of justifications consumers develop in response to persuasive messages (Fransen, Verlegh, Kirmani, \& Smit, 2015) that they find fair but are not willing to follow.

These justified counterarguments find support in the literature that explains the ethical purchase gap (Chatzidakis \& Lee, 2013; Chatzidakis, Hibbert, \& Smith, 2007) and motivated reasoning (Bhattacharjee, Berman, \& Reed, 2012; Kunda, 1990; Tsang, 2002). Neutralization techniques also help consumers legitimize inconsistent actions with norms and attitudes (Gruber \& Schlegelmilch, 2014). For example, small-agent phenomenon falls into the category of denial of responsibility under neutralization techniques, where people convince themselves that they are not personally responsible for any breach of social norms as this was caused by external factors outside their control (Sykes \& Matza, 1957). Perceived low selfefficacy may make a person believe that s/he has no control over external events, and thus, s/he cannot do anything about the transgression as an individual (Ajzen, 2002; Gifford, 2011). Thus, the degree of perceived behavioral control regarding the cause or the the outcome of a situation (Ajzen, 1991) might explain why people may show a positive attitude to a boycott call and agree with the importance of supporting it yet then remain inactive. Campbell (1963) attributes this inconsistency between an attitude and behavior to the cost of that specific behavior. Thus, an action is the function of the degree and magnitude of an attitude and the cost of the subsequent action (Kaiser, Byrka, \& Hartig, 2010).

In line with the literature discussed and the cost-benefit analysis account of smallagency theory (Klein et al., 2004), if would-be participants in a boycott call perceive themselves too small to make a difference they may become reluctant to boycott (Klein et al., 2004), particularly when the costs of an anti-consumption effort in the form of boycotting outweigh its benefits (John \& Klein, 2003). 
The current paper agrees with prior literature but also contributes additional arguments asserting that SAR can also be observed from a different perspective, new to boycott participation literature. Specifically, when consumers face numerous boycott calls from various organizations, most of them may seem important, equally desirable to support, and hard to trade-off (Xu et al., 2013). In such circumstances, one may realize that s/he has limited resources to support all calls (that deserve being supported), and thus, may feel too small to make a difference.

Perceived low self-efficacy may decrease perceptions of control over external events due to one's limited behavioral control (Ajzen, 2002). Self-efficacy refers to an individuals' confidence in their aptitude to influence events that may have an impact on their life and control over how these events happen (Bandura, 1997). Thus, self-efficacy is focused on being able to do things and control outcomes (Gifford, 2011). In the case of supporting a boycott call, realizing that one is unable to help most people in need, may decrease his or her perceptions of personal control and influence on events, and thus, self-efficacy. Lack of selfefficacy will increase perceptions of personal incompetence and insignificance, instigating a sense of frustration, which then may cause an individual to make no choice at all, when faced with the decision of supporting a boycott call. Such inaction may stem from the realization that helping one party may not help others, and thus, people may believe that they are not capable of "doing the right thing" or choosing the few correct calls to support. Thus, exposing participants to multiple boycott calls may highlight the fact that life is full of people in need, many of whom cannot be helped. Participants may then accept inequity and negative incidents as commonplace and unavoidable.

Combined, these realizations may lead to SAR, which comprises two dimensions. First, in line with prior literature, people may perceive themselves powerless as they believe they are too small to affect external events. Second, people may perceive these uncontrollable 
events as inevitable, and thus, accept general inequities in life. Furthermore, the number of boycott calls requesting support will increase the salience of the small-agency rationalization; that is, the salience of the belief as to whether a person feels too small to make a difference or not. Hence,

$\mathbf{H}_{2}$ : Compared with individuals exposed to a few boycott calls, individuals exposed to many boycott calls are more likely to experience the SAR, and thus, are less likely to sign the petition to support a boycott call.

\section{Overview of studies}

We test our hypotheses in two online experiments. Study 1 provides initial supporting evidence for the first hypothesis. We compare the percentage of participants who accepted signing a petition to support a boycott call when there was a set of 15 boycott calls versus when there was a set of three boycott calls (Haynes, 2009). More importantly, while aiming to replicate Study 1's results, Study 2 also demonstrates the underlying mechanism behind this process by investigating the mediating role of SAR, while ruling out alternative explanations. Further, Study 2 attempts to rule out the possible confounding effects of information overload, and controls for other factors, such as perceived success likelihood, trustworthiness of boycott calls, equity issue, perceived behavioral control, and brand familiarity. Finally, a post-test was conducted to address further concerns about the potential confounding effect of information overload.

\section{Study 1}

Study 1 aimed to test our prediction that people who are exposed to many boycott calls will be less likely to sign a petition to support a boycott than others who are exposed to only a few boycott calls. Specifically, a large choice-set of boycott calls comprises 15 brands 
and a small choice-set of boycott calls comprises three brands, which are randomly drawn from the 15 brands in the large choice-set. The use of three and 15 as representatives of small choice-sets and large choice-sets is consistent with previous studies in choice overload literature (Haynes, 2009; Sela, Berger, \& Liu, 2009).

We followed Morales, Amir, and Lee's (2017) suggestion to employ realistic experimental designs and measure actual behaviors. The authors recommend researchers to “... have participants engage in a behavior that is a proxy for the underlying construct,... have participants sign a petition instead of rating their level of agreement/disagreement with a certain policy." (p. 471). Accordingly, we attempted to increase the realism of our experiments by measuring a behavioral dependent variable. "A behavior carries some consequence that extends beyond indicating one's thoughts about a given matter (Morales et al., 2017, p. 470). In our specific context, the 'consequence' for participants' behavior was the effort or the 'cost' of explaining why they decided to sign a petition. To avoid demand effects, in the questionnaire we were clear that skipping this response would not affect participants' compensation.

\section{Method}

Sample. A between-subjects experimental design was used. The experiment was conducted online and participants were recruited from Amazon M-Turk $(n=313$; Mage $=$ $37.5, \mathrm{SD}=11.5$, range 18-80 years; 181 females, 126 males, 6 missing information).

Participants are US residents; they completed a survey for a small monetary compensation. $12.5 \%$ of participants were undergraduate students, $15.7 \%$ were postgraduate students, $70.0 \%$ were non-students, and $1.9 \%$ provided no information regarding their occupation. Regarding their annual combined household income, the three most frequently reported brackets were the 'less than $\$ 30,000$ ' $(17.6 \%)$, the $\$ \$ 100,000$ or more' $(16.7 \%)$, and the ' $\$ 30,000-39,999$ ' (13.4\%). By random assignment, 161 participants saw the boycott calls for three brands (i.e., 
small choice-set condition) and 152 participants saw the boycott calls for 15 brands (i.e., large choice-set condition).

Procedure. Participants were first introduced to the general topic of the study, namely, boycotting. To ensure that all participants understood the term correctly, a definition of consumer boycotts was provided: "Boycotts occur when consumers stop buying or using a company's products or services, because the company has done something wrong or unethical. As boycotts directly threaten sales and revenues, they are taken seriously by businesses. Any concerned group or individual can call a boycott.” They were then told that they were about to see a list of calls for boycotts. They were informed that the list was not in any particular order. To increase relevance, they were told that the boycott calls were solicited from their local newspaper. This information was aimed to increase participants' motivation to take part in the study and to ensure that findings were not confounded with participants' low motivation.

The boycott calls and the associated brands are real and were selected from the Ethical Consumer's website (www.ethicalconsumer.org). Ethical Consumer is a leading alternative consumer organization, uncovering the truth behind the brands and supporting the growth of the ethical market since 1987. In the set of boycott calls, each call targets one brand, and the description consists of the category (e.g., animal rights, political, human rights, etc.), the organization calling for the boycott, and the reason for boycott. Below is an example of a boycott call targeted at Adidas (for a complete list, see Appendix 1).

\section{Adidas}

Category: Animal Rights

Called by: Viva

Boycott call from Viva for using kangaroo skin to make some types of football boots. Adidas is phasing out the use of kangaroo leather by 98 percent over 12 months but will still use small amounts of it so the boycott continues. 
For participants in the small choice-set condition, three brands were randomly and evenly selected from the list of 15 brands that participants in the large choice-set condition saw. After reading the information about the boycott calls in the assigned choice-set, participants were asked questions about their perceptions of the size of the assigned choiceset, support for a boycott call, and demographics information. Some choice overload studies (e.g., Greifeneder, Scheibehenne, \& Kleber, 2010; Townsend \& Kahn, 2014) measure dependent variables after the manipulation checks. While it is reasonable to assume that measuring perceptions of overload before dependent variables (e.g., satisfaction, choice deferral) may influence judgements regarding the dependent variables (Schwarz \& Clore, 1983), researchers Diehl and Poynor (2010) found that the order of these questions (i.e., measuring perceptions of overload either before or after DV measures) did not result in such confounding effects.

Measures. To check whether the choice-set size manipulation was confirmed, participants were asked two questions (adapted from Hadar \& Sood, 2014): "How much choice do you feel you were offered in terms of the number of boycott calls" $(1=$ not enough choices, $7=$ a lot of choices), "When initially given the task to pick one brand or organization to boycott from the choice-set, what did you think about the choice-set size? $(1=\mathrm{I}$ had too few options to choose from, 7 = I had too many options to choose from).

To measure participants' support for boycott, a real behavioral measure of signing the petition to support a boycott call was used (Morales et al., 2017). Specifically, after reading the information from the assigned list of brands to be boycotted, participants were presented an open-ended question: "If you agree to sign a petition against one of the brands or organizations that you just read about, please write below "Yes" and explain in a sentence why. This will automatically be stored in the change.org website. If you are not willing to sign the petition, then you can skip this question." If participants responded to the question by 
typing "Yes" and explaining the reason, their responses were coded as 1. If participants skipped this question, their responses were coded as 0 .

To measure participants' motivation, participants were asked: "How motivated were you in doing this survey?" ( 1 = not at all motivated, 7 = completely motivated $)$.

\section{Results}

Manipulation check. Manipulation check questions $(r=.620)$ confirmed the success of the choice-set size manipulation, such that participants in the large choice-set condition perceived their choice-set as larger than the participants in the small choice-set condition (M $=5.48, \mathrm{SD}=1.30$ vs. $\mathrm{M}=3.42, \mathrm{SD}=1.29, t=-14.075, p<.001)$. There was also strong evidence that participants did report a high level of motivation while completing the survey $(\mathrm{M}=5.42$ vs. test value $=4$ (midpoint in the 7-point scale), $\mathrm{SD}=.855, \mathrm{t}=51.236, p<.001)$ The effect of choice-set size on motivation was not significant $(\mathrm{F}(1,311)=.197, p=.658)$.

Hypothesis testing. To test Hypothesis 1, a chi-square test was used. Results revealed that the number of participants choosing from the large choice-set condition who signed the petition $(28.3 \%)$ was less than the number of participants choosing from the small choice-set condition $\left(39.8 \%, \chi^{2}(1, n=313)=4.566, p=.033, \Phi=-.121\right)$. Thus, Hypothesis 1 was supported.

\section{Discussion of Study 1}

Study 1 provided preliminary support for our first hypothesis that being exposed to too many (vs. a few) boycott calls makes people less likely to sign a petition to support a boycott. However, a question remains unanswered: Is it the amount of information or the number of choices which drives the effect? Indeed, participants may have been affected by information overload rather than by choice overload. This would mean that the difference between the amount of information and not the number of choices might account for the difference in the percentage of participants who were willing to sign a petition to support a 
boycott in each choice-set condition. More importantly, the central question as to why being exposed to too many calls prevent people from signing a petition remained unanswered. Further, Study 1 did not control for potential confounding factors (covariates). All of these issues were addressed in Study 2.

\section{Study 2}

The first aim of Study 2 was to rule out the possibility of information overload (e.g., Jacoby, 1984) and not choice overload leading to fewer participants in the large (vs. small) choice set signing petitions. Information overload may be caused by the amount of information in the description of the boycott calls, which participants in the large choice-set condition had to process. Clearly, information overload is different than choice overload as it may be a result of a lot of information but not a lot of options (choices). To address this concern, Study 2 noticeably reduced the amount of information in the description of each boycott call (see the method section below). Second, Study 2 aims to build on Study 1 by not only replicating Study 1's results, but also demonstrating the underlying mechanism behind this effect by exploring the mediating role of SAR. The indirect effect of SAR was examined together with other alternative explanations of choice overload effects such as regret (Inbar, Botti, \& Hanko, 2011), choice difficulty (Iyengar \& Lepper, 2000), and feeling overwhelmed (Diehl \& Poynor, 2010) by measuring these constructs and checking their mediating effects.

Third, Study 2 aims to control for some other factors, such as perceived success likelihood (Sen et al., 2001), trustworthiness of boycott calls, equity issue, perceived behavioral control (Ajzen, 1991), and brand familiarity. The need for controlling these factors emerged for the following reasons. First, it is reasonable to assume that people who see many boycott calls might develop some doubts regarding the effectiveness and success of these boycotts or whether all these calls are indeed reliable and believable. Hence, we controlled 
for trustworthiness. Second, exposure to too many boycott calls may lead people to be concerned about their own perceived unjust behavior (i.e., alertness to personal inequity) when they boycott only one brand out of many. This is different than the "acceptance of general inequity in life" dimension in the SAR scale, which is about accepting the reality that the world is full of injustice. Third, we also controlled for perceived behavioral control (Ajzen, 1991), which reflects people's perception of their control over the occurrence or outcome of a situation. This is different from the powerlessness dimension of the SAR scale, which represents people's perception of their capability to carry out an action (e.g., boycotting a brand) to make a change (John \& Klein, 2003; Klein et al., 2004). Finally, as our experiment uses well-known brands, we measured brand familiarity with target brands and use them as a covariate in the analysis to control potential confounding effects.

\section{Method}

Sample. Study 2 was a two-group (choice-set size: small, large) between-subjects factorial design. Participants in the online experiment were recruited from Amazon M-Turk $\left(n=228 ; \mathrm{M}_{\mathrm{age}}=35.57, \mathrm{SD}=11.41\right.$, range 19-68 years; 119 females, 105 males, 4 missing information). Participants are US residents; they completed a survey for a small monetary compensation. $24.6 \%$ of the participants were undergraduate students, $14.9 \%$ were postgraduate students, $57.5 \%$ were non-students, and $3.1 \%$ did not provide information about their occupation. Regarding their annual combined household income, the three most frequently reported brackets were the 'less than $\$ 30,000$ ' $(19.2 \%)$, the ' $\$ 50,000$ - $\$ 59,999$ ' $(19.2 \%)$ and the ' $\$ 30,000-39,999 ’(12.3 \%)$. By random assignment, 114 participants saw the boycott calls for three brands (i.e., small choice-set condition) and 114 participants saw the boycott calls for 15 brands (i.e., large choice-set condition).

Procedure. The procedure of introducing the general topic of the questionnaire and the list of calls for boycotts was the same as in Study 1. However, to remove the confounding 
effect of information overload, the information explaining the boycott calls is reduced from a paragraph (as in Appendix 1) to a sentence (see Appendix 2). We also removed the categories of the causes because previous studies (Mogilner, Rudnick, \& Iyengar, 2008) found that having a mere presence of categories could alleviate the negative effect of an extensive choice-set. Below is an example of a boycott call targeted at Adidas (for a complete list, see Appendix 2).

\section{Adidas}

Boycott Adidas for using kangaroo skin to make football boots.

A separate post-test was conducted to address concerns that the amount of information in the large choice-set condition was still objectively more than that in the small choice-set condition. Following Baskin, Wakslak, Trope and Novemsky's (2014) approach, we ran a post-test using a student sample. $\left(\mathrm{n}=120, \mathrm{M}_{\mathrm{age}}=21.9, \mathrm{SD}=4.79,77.5 \%\right.$ female, $\left.\mathrm{n}_{\text {LargeChoiceSet }}=60, \mathrm{n}_{\text {SmallChoiceSet }}=60\right)$ at a large Australian university. Students were asked to read the information on boycott calls and, by randomization, they either received a small choice-set with three boycott calls or a large choice-set with 15 boycott calls, same as in the main study. We measured perceived information overload by asking two questions on a 7point scale: "How would you perceive the information you've just read?" ( 1 = Not a lot of information, 7 = Too much information); "The information regarding calls to boycott different brands is..." $(1=$ Not a lot, $7=$ A lot $)$. Results from a one-way ANOVA revealed that participants in the large choice-set $(\mathrm{M}=4.35, \mathrm{SD}=1.10)$ perceived that the amount of information not significantly more than did participants in the small choice-set $(\mathrm{M}=4.00, \mathrm{SD}$ $=1.19, F(1,118)=2.795, p=.097)$. We also measured the time (seconds) participants spent in reading the given information. Results revealed that there were no significant differences in reading time between participants in the large choice-set $(\mathrm{M}=81.45, \mathrm{SD}=84.81)$ and 
those in the small choice-set $(\mathrm{M}=73.76, \mathrm{SD}=172.01, F(1,118)=.097, p=.757)$. Thus, based on the empirical evidence, it could be concluded that information overload could be ruled out as a confounding factor.

In Study 2, after reading the information about the brands in the assigned choice-set, participants were asked questions about their perceptions of the size of the assigned choiceset, support for a boycott call, SAR, other factors, which could have functioned as alternative explanations and control variables causing the effect as mentioned earlier, and demographics information.

Measures. Measures of the choice-set size manipulation checks and the behavioral measure of signing the petition to support a boycott call were as in Study 1 .

Our theorization of SAR suggests that this factor has two components: powerlessness and acceptance of inequity in life. We asked participants to indicate their agreement on a 7point Likert scale $(1=$ strongly disagree, $7=$ strongly agree $)$ for seven statements, which comprise items of the SAR scale: (1) I alone cannot help to make the world a better and safer place, (2) I alone cannot act on all of these important issues, (3) I feel like I am incapable of making a positive change on this planet, (4) This is life, I cannot save the affected by boycotting only one brand or organization, (5) After reading about these brands, I feel like life is unfair overall, (6) After reading about these brands, I feel like there is no justice overall, and (7) After reading about these brands, I feel like the world lacks equality overall. The first four factors measured powerlessness, and the last three factors measured acceptance of inequity in life.

To measure perceived regret, we asked participants to indicate their perceived regret for their decision on a 7-point scale: "Given you cannot change your mind now, do you regret your choice?" ( 1 = No regret at all, 7 = Very much regret); "Do you think that another brand 
from the list would have been better to be boycotted than the brand you chose?" $(1=$ Definitely not, 7 = Definitely yes).

To measure choice difficulty, we asked: "How easy or difficult was it for you to choose a brand or organization to boycott?" (7-point scale, 1 = Very easy, 7 = Very difficult).

To measure feeling overwhelmed, we asked participants the following question on a 7-point scale: "How overwhelmed were you when looking at these boycott calls?" $(1=$ Not overwhelmed at all, $7=$ Very overwhelmed).

To measure perceived success likelihood of the boycott calls (adapted from Sen et al., 2001), we asked participants to indicate their agreements on a 7-point Likert scale $(1=$ strongly disagree, 7 = strongly agree) for two statements: "Boycotting these brands is an effective way to make them act responsibly," and "I am confident that boycotting these brands will ensure that they become responsible for their actions" $(r=.692)$.

To measure the boycott calls' trustworthiness, adapted from Albrecht, Campbell, Heinrich and Lammel (2013), we asked participants to indicate on a 7-point scale the extent to which they find the boycott calls unbelievable/believable, untrustworthy/ trustworthy, not convincing/ convincing, not credible/ credible, unreasonable/ reasonable, dishonest/ honest, questionable/ unquestionable, inconclusive/ conclusive, not authentic/ authentic, and unlikely/ likely $(\alpha=.958)$.

To measure the extent to which participants focused on the equity issue of choosing only one brand to boycott (alertness to personal inequity), we asked two questions on a 7point scale $(r=.605)$ : "To what extent do you find it is unfair if you can only select one brand to boycott?" (7-point scale, 1 = not at all unfair, 7 = very unfair), and "Is there an equity issue if you can only select one brand to boycott?" (7-point scale, 1 = no equity issue at all, $7=$ yes, very much). 
Adapting from Fielding, McDonald, and Louis (2008), we measured perceived behavioral control, asking participants the following five questions $(\alpha=.834)$ on the 7-point scale: "How much control do you have over whether you engage in boycotting these brands?" ( 1 = very little control, 7 = a great deal of control), "For me to engage in boycotting these brands is..." ( 1 = very difficult, 7 = very easy), "If I wanted to, I could easily engage in boycotting these brands." ( 1 = strongly disagree, 7 = strongly agree $)$, "It is mostly up to me whether I engage in boycotting these brands." $(1=$ strongly disagree, $7=$ strongly agree $)$, and "How difficult would it be for you to engage in boycotting these brands?" $(1$ = very difficult, $7=$ very easy).

Finally, to measure brand familiarity, participants were asked two questions on a 7point scale $(r=.776)$ : "How familiar are you with the brands and organizations included in the list for boycotting?" ( 1 = not at all familiar, 7 = very familiar), "How well do you know the brands and organizations included in the list for boycotting? $(1=$ not at all, $7=$ very much).

\section{Results}

Manipulation check. Manipulation check questions $(r=.742)$ confirmed the success of the choice-set size manipulation, such that participants in the large choice-set condition (M $=5.36, \mathrm{SD}=1.48)$ perceived their choice-set as larger than the participants in the small choice-set condition $(\mathrm{M}=3.08, \mathrm{SD}=1.54, t=-11.377, p<.001)$.

Reliability and validity. Given the novelty of the SAR scale, we investigated the reliability and validity of the scale. First, the coefficient alpha for the whole scale is .781. For powerlessness items (items 1-4), the Cronbach's alpha is .709. For acceptance of inequity in life (items 5-7), the Cronbach's alpha is .862. Second, a principle component analysis (PCA) followed by Varimax rotation was conducted. The PCA produced a two-component solution, based on the following criteria: "eigenvalue $(>1)$, scree plot (retain all components within the 
sharp descent), loading score for each factor $(\geq 0.40)$, and meaningfulness of each dimension (Aaker, 1997; Nunnally, 1978)" (cited in Sung, Choi, Ahn, \& Song, 2015, p. 126). There was evidence of convergent validity as factor loadings were greater than .5 after Varimax rotation. As these measurement items converged on to the original proposed factors, there was evidence of good construct validity (Kaiser \& Rice, 1974).

Third, a confirmatory factor analysis (CFA) was conducted in AMOS 25.0. The data did fit the model, based on multiple goodness-of-fit indices: (1) the chi-square statistic was significant $\left(\chi^{2}=25.811, \mathrm{df}=13, \mathrm{p}=.018\right)$ but the $\chi 2 / \mathrm{df}$ ratio was 1.985 , smaller than $3,(2)$ CFI (.975), GFI (.971), NFI (.952), and IFI (.975) were higher than 0.90, (3) RMSEA was .066. In support of convergent validity, the loadings on the factors were significant $(\mathrm{p}<$ $.001)$. All the factor loadings were $>.5$. We examined the discriminant validity using the Fornell and Larcker (1981) technique: using the square root of AVE of each construct is greater than the correlation of the specific construct with the other construct.

We also compared different models: a single-factor model in which all 7 items explained one latent construct (Model A), a 2-factor model (Model B), a 2-factor model with one higher order factor (Model C). Results revealed that Model A did not fit well (e.g., $\chi 2 / \mathrm{df}$ ratio was 9.393, larger than $3 ; \mathrm{CFI}=.771, \mathrm{IFI}=.774, \mathrm{RMSEA}=.192)$, and Models $\mathrm{B} \& \mathrm{C}$ have identical fit indices (because there are only two first-order factors). The abovementioned results provide empirical supports that the SAR construct is effectively measured, with two dimensions: powerlessness and acceptance of inequity in life.

Hypothesis testing. To test Hypothesis 1, a chi-square test was used. Results revealed that the number of participants choosing from the large choice-set condition who signed the petition (37.7\%) was less than the number of participants choosing from the small choice-set condition who signed the petition $\left(51.8 \%, \chi^{2}(1, n=228)=4.542, p=.033, \Phi=-.141\right)$. Thus, Hypothesis 1 was again supported. 
Mediation analysis. To examine whether SAR (mediator) explained the effect of choice-set size (independent variable) on signing a petition to support a boycott call (dependent variable), a series of regressions and 10,000 bootstrap resamples using the PROCESS macro for SPSS (model 4; Hayes, 2013), as recommended by Zhao, Lynch, and Chen (2010), were performed. Five covariates included in the model were: perceived success likelihood, trustworthiness of boycott calls, equity issue (i.e., alertness to personal inequity), perceived behavioral control, and brand familiarity. Other competing mechanisms were regret, choice difficulty, and feeling overwhelmed.

Results revealed that the indirect effect of choice-set size on signing a petition through SAR was significant $(\beta=-.0618, \mathrm{SE}=.0490,95 \% \mathrm{CI}=[-.1921,-.0019])$. Importantly, the indirect effects of choice-set size through regret $(\beta=.0057, \mathrm{SE}=.0280,95 \%$ $\mathrm{CI}=[-.0419, .0797])$, choice difficulty $(\beta=-.0055, \mathrm{SE}=.0220,95 \% \mathrm{CI}=[-.0716, .0243])$, and feeling overwhelmed $(\beta=.0240, \mathrm{SE}=.0673,95 \% \mathrm{CI}=[-.1044, .1660])$ were not significant.

When these alternative explanations were removed, the indirect effect of choice-set size through SAR remained significant $(\beta=-.0610, \mathrm{SE}=.0476,95 \% \mathrm{CI}=[-.1931,-.0031])$. When all alternative explanations and covariates were removed, the indirect effect of choiceset size through $\mathrm{SAR}$ also remained significant $(\beta=-.0774, \mathrm{SE}=.0449,95 \% \mathrm{CI}=[-.1902,-$ $.0150]$ ) while the direct effect of choice-set size became insignificant (Cohen's $d=-.2213$, $\mathrm{SE}=.1384, p=.110,95 \% \mathrm{CI}=[-.4926, .0499])$. When the covariates were removed but the alternative mechanisms were still included in the mediation model, results revealed that only the indirect effect of choice-set size on signing a petition through SAR was significant $(\beta=-$ $.0821, \mathrm{SE}=.0477,95 \% \mathrm{CI}=[-.2014,-.0154])$ while the indirect effects of choice-set size through regret $(\beta=.0236, \mathrm{SE}=.0343,95 \% \mathrm{CI}=[-.0314, .1109])$, choice difficulty $(\beta=-$ $.0299, \mathrm{SE}=.0332,95 \% \mathrm{CI}=[-.1170, .0216])$, and feeling overwhelmed $(\beta=.0852, \mathrm{SE}=$ 
$.0696,95 \% \mathrm{CI}=[-.0337, .2428])$ and the direct effect of choice-set size (Cohen's $\mathrm{d}=-.3039$, $\mathrm{SE}=.1502, p=.0430,95 \% \mathrm{CI}=[-.5982,-.0095])$ were significant.

Thus, there was supporting evidence for Hypothesis 2 such that SAR mediated the effect of choice-set size on signing a petition. Figure 1 and Table 1 summarize relevant regression analyses between constructs.

\section{(Insert Figure 1 here)}

\section{(Insert Table 1 here)}

\section{Discussion of Study 2}

While controlling for the potential confounding effect of information overload, Study 2 replicated Study 1's results such that participants were less likely to sign a petition to support a boycott if they are exposed to too many (vs. a few) boycott calls. More importantly, this effect was driven by the mediation effect of SAR. Thus, when being exposed to a large (vs. small) choice-set of boycott calls, participants were more likely to feel small such that they felt the sense of being powerless and also accepted unfairness in the world, which led to their unwillingness to sign a petition.

Table 1 provided further insights regarding the effects of the covariates. Results revealed that perceived behavioral control, brand familiarity, and trustworthiness of boycott calls $(p s>.6)$ did not influence whether participants experienced being a small-agent. Yet, the feeling of small-agency is negatively affected by perceived success likelihood $(p=.001)$ and positively affected by perceptions of personal equity issue $(p=.007)$. These findings support our theoretical arguments regarding SAR. Specifically, as perceptions of boycott success likelihood increase, feelings of small-agency decrease. Conversely, when individuals believe there is an equity issue when supporting only one boycott, feelings of small-agency increase. Regarding the likelihood to sign a petition to support a boycott, results revealed that 
perceived success likelihood, equity issue, perceived behavioral control, and brand familiarity did not have significant effects $(p s>.2)$. Yet, only when participants perceived the boycott calls to be trustworthy, they were more likely to sign a petition $(\mathrm{p}<.001)$.

Results of the post-test addressing information overload concerns confirm that participants devoted a similar amount of time into both high and low information conditions, which suggests that people only have a certain amount of time and cognitive resources they are willing to devote to various issues. Thus, when faced with more information, most people still devote approximately the same amount of effort (e.g., time) as in low information scenarios. In any case, based on the empirical evidence, we show that we have ruled out information overload as an alternative account for our research findings. Essentially, participants (and people in the real world) bypass information overload by refusing to devote anymore cognitive and time resources, therefore information overload does not occur.

\section{General Discussion and Conclusion}

Organizations and people asking consumers to sign a petition against transgressing brands has become commonplace for consumers on social media every day. Yet, marketing and consumer behavior literature has not paid attention to the rising popularity of consumers signing online petitions. Thus, literature on this trend is limited. Exploring the impact of choice overload on consumers signing a petition in support of a boycott call, this study establishes that individuals who need to make a choice from numerous boycott calls (i.e., large choice-sets) are less likely to sign a petition to support the boycott call than those who need to make a choice from a small number of boycott calls.

The findings also support a theoretical rationale explaining this effect. Compared with individuals facing fewer boycott calls, those facing numerous boycott calls are more likely to 
experience the SAR, and thus, are less likely to sign the petition. Unlike the small-agent phenomenon in prior literature that only focuses on one's inability to compete against large companies, the SAR we established in this research additionally refers to one's acceptance of inequity in the world, and thus, one's inability to help everyone in need. Being 'small,' and therefore, inept and ineffective against big players (i.e., organizations) in the marketplace decreases likelihood to boycott (Klein et al., 2004). This study offers choice-set size as a novel antecedent that leads to SAR. Specifically, this study establishes that being exposed to too many boycott calls will increase the salience of many important events that one cannot support simultaneously, due to limited personal capacity.

Credibility and trustworthiness of the source and content of information on persuasion is well established (Balabanis \& Chatzopoulou, 2019). The more reputable or expert a spokesperson or an organization and the higher the consumer perceptions of the accuracy and reliability of the information provided, the more persuasive the message becomes (Metzger $\&$ Flanagin, 2013; Ohanian, 1990; Rieh, 2002). Sen et al. (2001) support this view by stating the necessity of the source credibility regarding the boycott organizers or boycott messages to be investigated in further boycott studies. Following their call, we measured the effect of source credibility (Albrecht et al., 2013) on boycott support and found that it has a significant effect as expected.

\section{Theoretical contributions}

This study contributes to anti-consumption (e.g., Chatzidakis \& Lee, 2013) and boycott literature (e.g., Hoffmann, 2011; Yuksel \& Mryteza, 2009) by introducing a new antecedent that influences anti-consumption related decisions (Lee, Fernandez, \& Hyman, 2009; Yuksel, 2013); namely, the effect of many versus few boycott calls. This is the first study establishing that the number of requests asking for anti-consumption will influence 
consumers' decisions to support a boycott call or to do nothing. By the same token, this study also adds directly to the boycott literature a new outcome variable (dependent variable), which not only measures attitudes but also actual behavior. Consequently, this study increases the realism of experimental research (Morales et al., 2017). In our studies, participants were asked whether they would agree to sign a petition against one of the brands listed on a boycott website. Participants were told that they need to select one out of the two decisions. They were told that they either choose "Yes" as a response to the question relating to boycott support, or, alternatively, they could choose to skip the question, should they decide not to support the boycott. Specifically, participants read the following requirement. "If you agree to sign a petition against one of the brands/organizations that you just read, please write below "Yes" and explain in a sentence why. This will automatically be stored in the change.org website. If you are not willing to sign the petition, then skip this question." Thus, the dependent variable used in this study measured actual boycott behavior in terms of signing an online petition. More importantly, the introduction of a new antecedent to boycott likelihood; that is, the number of calls to which consumers are exposed to, expands boycott literature. The study establishes that the greater the number of boycott calls consumers receive, the less they will participate in boycotts. Indeed, given there are so many calls on the Internet and social media that ask customers to sign a petition, it is very important for boycott organizers or initiators of petitions to know whether the number of current calls will have an impact on their targets.

Likewise, this study contributes to choice overload literature (e.g., Papadopoulou, Raïes, Mir Bernal, \& Woodside, 2019) by introducing a new outcome variable; namely, a decision to support boycotts by signing a petition when faced with numerous versus limited options. Indeed, while on the surface it may seem that we have simply replicated prior research on choice overload, we actually contribute to the literature in three ways. First, the 
context is novel and looks at the effect of choice overload on anti-consumption rather than consumption. Second, at the theoretical level, the introduction of SAR explains inaction in the boycotting context that may not apply to regular consumption contexts. Third, from a conceptual perspective, boycotting is a different construct from non-choice. The decision not to boycott has more dire consequences, since refusing to boycott a business in the face of the information about the egregious company may be accompanied by a greater variety of negative feelings. Prior research on choice overload (Chernev et al., 2015) suggests that nonchoice/inaction enables people to avoid post purchase regret and does not lead to psychological repercussions such as feelings of guilt, being unethical, irresponsible, powerless, and so forth. In contrast, our research on boycott overload suggests the opposite, where inaction may be accompanied by those very same negative feelings. In conventional cases of choice overload, usually relating to purchase decisions, consumers who are faced with too many purchase options, feel a sense of regret (Scheibehenne, Greifeneder, \& Todd, 2010) or dissatisfaction with their decision (Haynes, 2009; Thai \& Yuksel, 2017). In some cases, they may even decide to forego a purchase (Chernev et al., 2015). However, the current research extends this literature by demonstrating that choice overload, in the context of anti-consumption (via boycotting), can also cause people to accept inequity in the world, which then prevents them from acting on moral decisions. Therefore, the effect of choice overload, in terms of deciding whether to practice anti-consumption or not, is more critical than choice overload in purchase/consumption decisions. The reason being that, whilst choice overload has a negative impact on consumer decision making, it does not evoke the same sense of powerlessness, which choice overload can have in cases of anti-consumption.

Classic small-agent conceptualization (John \& Klein, 2003) that relates to being weak and powerless in the presence of the strong and powerful, only partially explains the severe effect of choice overload in anti-consumption calls. The current study extends the theory 
further by proposing the concept of SAR, which is a more complex phenomenon than the small-agent concept covered in prior literature and economics (Orland \& Selten, 2016; Tyran \& Engelmann, 2005).

In the present study, people facing many requests to practice anti-consumption not only perceive themselves "too small" to make a difference (John \& Klein, 2003), and thus, feel ineffective and inept to "do the right thing", but also, they align this lack of self-efficacy with a perception of the world being inherently inequitable. Thus, the current research augments small-agency concept as it contributes an additional dimension: acceptance of general inequity in life. This amplification makes the small-agency conceptually and empirically different from the small-agent theory in economics and prior work that relates to a rational analysis of costs versus benefits or to imperfect competition (Crawford, Pavanini, \& Schivardi, 2018). For example, John and Klein (2003) state that after weighing costs against benefits, if people realize that the cost of participation may outweigh the benefits gained, people may decide not to boycott. This is because their contribution may not be big enough to change "one" important boycott call, which is bigger than their self. Yet, this effect is eliminated once people believe that the boycott will be successful (John \& Klein, 2003). However, in our current conceptualization, even if the boycott a person participates in is expected to be successful, there remains many other calls worth boycotting, with which the individual cannot help. Thus, in the context of anti-consumption, the small-agent rationalization is further associated with accepting unfairness and inequity in the world. Ironically, as social media and the Internet open channels for putting forth a plethora of boycott calls, more consumers may start to tolerate unfairness and inequality, as they notice their inability to help all charity organizations that are facing various tragedies. In addition to the conceptualization of SAR, the current research also empirically measures this new construct, using a 7-item scale, not developed and empirically tested before (see Method 
section for details). The two-dimensional SAR scale has two components : powerlessness and acceptance of inequity in life. Thus, the current work expands the construct of small-agency beyond the original cost-benefit perspective (Klein et al., 2004).

\section{Managerial and policy implications}

In terms of managerial and practical implications, this study provides boycott organizers as well as policy makers with information on how to manage successful boycott calls and increase signatures for online petitions. While it seems exciting for an organization to list all current boycott calls in order to attract more potential supporters, the findings here suggest that people are actually less likely to sign a petition — which is what really matters for the organization - when people see too many boycott calls. Boycott organizers, therefore, should be selective in terms of choosing which brand they prioritize to be boycotted. A timeline that partitions different boycott campaigns to be promoted at different periods is recommended as participants may perceive such an approach as less overwhelming. People may then be less likely to perceive themselves as "too small" to make a difference, or even worse, come to accept inequity in the world. Practically speaking, findings from this study suggest that social media channels, where people share their support for a campaign or make an announcement that they are boycotting a specific brand, should consider modifying their algorithms so that users will not see too many boycott calls on their News Feed at a time.

Another managerial implication relates to some ethical concerns regarding the genuineness of the boycott calls and organizers. Along this present study, we introduce boycott calls as a legitimate consumer action and present information to help increase the marketing effectiveness of organizations proposing those boycotts. Although boycotts motivate consumers by instilling a sense of consumer empowerment (Gonçalves, Silva, \& Martins, 2018), this empowerment may sometimes be distorted and misused by consumers, 
boycott organizers, or competing brands. Thus, trustworthiness of the source is included as a covariate in Study 2. Several unjust anti-consumption practices may stem from consumers following a boycott call that is unreal, unfair, or exaggerated with the adverse purpose of damaging a brand. Such smear campaigns are quite easy to facilitate and may have fast, widespread effects in the current era of fake news and post-truth, expediated by the new mechanisms of neo-liberalism. In such cases, boycott targeted brands should be equipped with sound armaments to strategically respond to such boycott calls (Dutta \& Pullig, 2011; Yuksel \& Mryteza, 2009). Indeed, boycott research details strategic actions to be followed by boycott targeted firms to avoid or diminish the negative effects of boycott calls (see Yuksel \& Mryteza, 2009 for detailed discussion on four different strategic responses boycott targeted companies follow).

\section{Limitations and further research}

This study is not immune to some limitations. Although the study establishes that choice overload occurs when people encounter too many boycott calls, there may be boundary conditions on this effect, which this study did not investigate. For instance, the effect of brand familiarity on SAR warrants further investigation, despite brand familiarity not having a subsequent effect on boycott support. Nonetheless, the effects of choice overload on unfamiliar brands is ripe for investigation. Additionally, whilst this current study establishes that SAR is the underlying process explaining the effect of choice-set size on boycott support decisions, there remain factors that may affect one's perceptions of SAR, such as personality traits and culture, which were beyond the scope of this study, and thus, not investigated. Further studies may delve into dynamics that may influence one's sense of self and self-efficacy, which may then affect one's SAR. 
Furthermore, although assessing real behavior in experiments have many benefits, this approach does have a limitation. For example, the measurement of boycott support by asking participants to write "Yes" and explain their reasons as to why they agreed to support the boycott (i.e., replicating how petition sites like Change.org work) may introduce some social desirability bias resulting in demand effects among MTurk participants. Thus, further studies may choose to employ field experiments to test the realism and external validity, thus replicating the effects found in this research. This will also address the challenge caused by measuring a real behavior in an online experiment. For example, future studies may create a mock-up website, like the Ethical Consumer site referenced in this present research, and then feature either a small or large choice-set of boycott calls to see if more people join a boycott when a small (vs. large) choice-set of calls is displayed. Alternatively, further studies may run field studies using clipboards to have individuals potentially sign a petition on the road. 


\section{References}

Aaker, J., Fournier, S., \& Brasel, S. A. (2004). When good brands do bad. Journal of Consumer Research, 31(1), 1-16.

Ahluwalia, R. (2000). Examination of psychological processes underlying resistance to persuasion. Journal of Consumer Research, 27(2), 217-232.

Ajzen, I. (1991). The theory of planned behavior. Organizational Behavior and Human Decision Processes, 50(2), 179-211.

Ajzen, I. (2002). Perceived behavioral control, self-efficacy, locus of control, and the theory of planned behavior. Journal of Applied Social Psychology, 32(4), 665-683.

Albrecht, C. M., Campbell, C., Heinrich, D., \& Lammel, M. (2013). Exploring why consumers engage in boycotts: Toward a unified model. Journal of Public Affairs, 13(2), 180-189.

Antonetti, P., \& Manika, D. (2017). The offline spill-over of signing online petitions against companies: A dual pathway model. Information Technology \& People, 30(4), 969-990.

Arendt, H. (1972). Crises of the republic: Lying in politics, civil disobedience on violence, thoughts on politics, and revolution (Vol. 219). Houghton Mifflin Harcourt.

Balabanis, G., \& Chatzopoulou, E. (2019). Under the influence of a blogger: The role of information-seeking goals and issue involvement. Psychology \& Marketing, 36(4), $342-353$.

Bandura, A. (1997). Self-efficacy: The exercise of control. New York, NY: Macmillan.

Baskin, E., Wakslak, C. J., Trope, Y., \& Novemsky, N. (2014). Why feasibility matters more to gift receivers than to givers: A construal-level approach to gift giving. Journal of Consumer Research, 41(1), 169-182.

Bhattacharjee, A., Berman, J. Z., \& Reed, A. (2012). Tip of the hat, wag of the finger: How moral decoupling enables consumers to admire and admonish. Journal of Consumer Research, 39(6), 1167-1184.

Campbell, D. T. (1963). Social attitudes and other acquired behavioral dispositions.

Change.org. (n.d.-a). @Uber: Stop the double standards. Mandate a 7 year background check for all Uber drivers in India like in the US. Retrieved from https://www.change.org/p/uber-uber-stop-the-double-standards-mandate-a-7-yearbackground-check-for-all-uber-drivers-in-india-like-in-the-

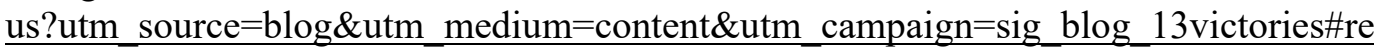
sponse-26121

Change.org. (n.d.-b). Business Model. Retrieved from https://www.change.org/about/business-model

Change.org. (2016). 13 Victories that Changed the World. Retrieved from https://www.change.org/1/us/13-victories-that-changed-the-world 
Chatzidakis, A., Hibbert, S., \& Smith, A. P. (2007). Why people don't take their concerns about fair trade to the supermarket: The role of neutralisation. Journal of Business Ethics, 74(1), 89-100.

Chatzidakis, A., \& Lee, M. S. W, (2013). Anti-consumption as the study of reasons against. Journal of Macromarketing, 33(3), 190-203.

Chernev, A., Böckenholt, U., \& Goodman, J. (2015). Choice overload: A conceptual review and meta-analysis. Journal of Consumer Psychology, 25(2), 333-358.

Crawford, G. S., Pavanini, N., \& Schivardi, F. (2018). Asymmetric information and imperfect competition in lending markets. American Economic Review, 108(7), 16591701.

Diehl, K., \& Poynor, C. (2010). Great expectations?! Assortment size, expectations, and satisfaction. Journal of Marketing Research, 47(2), 312-322.

Drolet, A., \& Luce, M. F. (2004). The rationalizing effects of cognitive load on emotionbased trade-off avoidance. Journal of Consumer Research, 31(1), 63-77.

Dutta, S., \& Pullig, C. (2011). Effectiveness of corporate responses to brand crises: The role of crisis type and response strategies. Journal of Business Research, 64(12), 12811287.

Ettenson, R., Smith, N. C., Klein, J., \& John, A. (2006). Rethinking consumer boycotts. MIT Sloan Management Review, 47(4), 6-7.

Fielding, K. S., McDonald, R., \& Louis, W. R. (2008). Theory of planned behaviour, identity and intentions to engage in environmental activism. Journal of Environmental Psychology, 28(4), 318-326.

Fornell, C., \& Larcker, D. F. (1981). Evaluating structural equation models with unobservable variables and measurement error. Journal of Marketing Research, 18(1), $39-50$.

Forno, F., \& Graziano, P. R. (2014). Sustainable community movement organisations. Journal of Consumer Culture, 14(2), 139-157.

Fransen, M. L., Verlegh, P. W., Kirmani, A., \& Smit, E. G. (2015). A typology of consumer strategies for resisting advertising, and a review of mechanisms for countering them. International Journal of Advertising, 34(1), 6-16.

Friedman, M. (1999). Consumer boycotts. New York: Routledge

Garrett, D. E. (1987). The effectiveness of marketing policy boycotts: Environmental opposition to marketing. Journal of Marketing, 51(2), 46-57.

Gifford, R. (2011). The dragons of inaction: psychological barriers that limit climate change mitigation and adaptation. American Psychologist, 66(4), 290.

Gonçalves, H. M., Silva, G. M., \& Martins, T. G. (2018). Motivations for posting online reviews in the hotel industry. Psychology \& Marketing, 35(11), 807-817. 
Greifeneder, R., Scheibehenne, B., \& Kleber, N. (2010). Less may be more when choosing is difficult: Choice complexity and too much choice. Acta Psychologica, 133(1), 45-50.

Gruber, V., \& Schlegelmilch, B. B. (2014). How techniques of neutralization legitimize norm-and attitude-inconsistent consumer behavior. Journal of Business Ethics, 121(1), $29-45$.

Hadar, L., \& Sood, S. (2014). When knowledge is demotivating: Subjective knowledge and Choice overload. Psychological Science, 25(9), 1739-1747.

Hayes, A. F. (2013). Introduction to mediation, moderation, and conditional process analysis. New York, NY: Guilford.

Haynes, G. A. (2009). Testing the boundaries of the choice overload phenomenon: The effect of number of options and time pressure on decision difficulty and satisfaction. Psychology \& Marketing, 26(3), 204-212.

Hennig-Thurau, T., Gwinner, K. P., Walsh, G., \& Gremler, D. D. (2004). Electronic word-ofmouth via consumer-opinion platforms: what motivates consumers to articulate themselves on the internet?. Journal of Interactive Marketing, 18(1), 38-52.

Hirschman, A. O. (1970). Exit, voice, and loyalty: Responses to decline in firms, organizations, and states. Cambridge: Harvard University Press.

Hoffmann, S. (2011). Anti-consumption as a means to save jobs. European Journal of Marketing, 45(11/12), 1702-1714.

Hoffmann, S. (2013). Are boycott motives rationalizations? Journal of Consumer Behaviour, 12(3), 214-222.

Hoffmann, S., Balderjahn, I., Seegebarth, B., Mai, R., \& Peyer, M. (2018). Under Which Conditions Are Consumers Ready to Boycott or Buycott? The Roles of Hedonism and Simplicity. Ecological Economics, 147, 167-178.

Hoffmann, S., \& Hutter, K. (2012). Carrotmob as a new form of ethical consumption. The nature of the concept and avenues for future research. Journal of Consumer Policy, 35(2), 215-236.

Humphreys, A., \& Thompson, C. J. (2014). Branding disaster: Reestablishing trust through the ideological containment of systemic risk anxieties. Journal of Consumer Research, 41(4), 877-910.

Inbar, Y., Botti, S., \& Hanko, K. (2011). Decision speed and choice regret: When haste feels like waste. Journal of Experimental Social Psychology, 47(3), 533-540.

Iyengar, S. S., \& Lepper, M. R. (2000). When choice is demotivating: Can one desire too much of a good thing? Journal of Personality and Social Psychology, 79(6), 995-1006.

Jacoby, J. (1984). Perspectives on information overload. Journal of Consumer Research, $10(4), 432-435$. 
John, A., \& Klein, J. (2003). The boycott puzzle: consumer motivations for purchase sacrifice. Management Science, 49(9), 1196-1209.

Kaiser, F. G., Byrka, K., \& Hartig, T. (2010). Reviving Campbell's paradigm for attitude research. Personality and Social Psychology Review, 14(4), 351-367.

Kaiser, H. F., \& Rice, J. (1974). Little jiffy, mark VI. Educational and Psychological Measurement, 34(1), 111-117.

Klein, J. G., Smith, N. C., \& John, A. (2004). Why we boycott: Consumer motivations for boycott participation. Journal of Marketing, 68(3), 92-109.

Kunda, Z. (1990). The case for motivated reasoning. Psychological Bulletin, 108(3), 480498.

Lasarov, W., Mai, R., de Frutos, N. G., Egea, J. M. O., \& Hoffmann, S. (2019). Counterarguing as barriers to environmentally motivated consumption reduction: A multicountry study. International Journal of Research in Marketing.

Lee, B. K., \& Lee, W. N. (2004). The effect of information overload on consumer choice quality in an on-line environment. Psychology \& Marketing, 21(3), 159-183.

Lee, M. S. W., Fernandez, K. V., \& Hyman, M. R. (2009). Anti-consumption: An overview and research agenda. Journal of Business Research, 62(2), 145-147.

Lee, M. S. W., Motion, J., \& Conroy, D. (2009). Anti-consumption and brand avoidance. Journal of Business Research, 62(2), 169-180.

Lee, Y. H., \& Hsieh, G. (2013). Does slacktivism hurt activism? The effects of moral balancing and consistency in online activism. Proceedings of the SIGCHI conference on human factors in computing systems, 13, 811-820.

Metzger, M. J., \& Flanagin, A. J. (2013). Credibility and trust of information in online environments: The use of cognitive heuristics. Journal of Pragmatics, 59, 210-220.

Mogilner, C., Rudnick, T., \& Iyengar, S. S. (2008). The mere categorization effect: How the presence of categories increases choosers' perceptions of assortment variety and outcome satisfaction. Journal of Consumer Research, 35(2), 202-215.

Morales, A. C., Amir, O., \& Lee, L. (2017). Keeping it real in experimental researchUnderstanding when, where, and how to enhance realism and measure consumer behavior. Journal of Consumer Research, 44(2), 465-476.

Morozov, E. (2012). The net delusion: The dark side of Internet freedom. Public Affairs.

Ohanian, R. (1990). Construction and validation of a scale to measure celebrity endorsers 'perceived expertise, trustworthiness, and attractiveness, Journal of Advertising, 19(3), $39-52$.

Orland, A., \& Selten, R. (2016). Buyer power in bilateral oligopolies with advance production: Experimental evidence. Journal of Economic Behavior \& Organization, 122, 31-42. 
Papadopoulou, N., Raïes, K., Mir Bernal, P., \& Woodside, A. G. (2019). Gifts as conduits in choice overload environments. Psychology \& Marketing, 36(7), 716-729.

Papaoikonomou, E., \& Alarcón, A. (2017). Revisiting consumer empowerment: An exploration of ethical consumption communities. Journal of Macromarketing, 37(1), 40-56.

Parigi, P., \& Gong, R. (2014). From grassroots to digital ties: a case study of a political consumerism movement. Journal of Consumer Culture, 14(2), 236-253.

Resnick, P. (2002). Beyond bowling together: sociotechnical capital. In J. Carroll (Ed.), Human Computer Interaction in the New Millennium (pp. 247-272). New York: Addison-Wesley.

Rieh, S. Y. (2002). Judgment of information quality and cognitive authority in the web. Journal of the American Society for Information Science and Technology, 53, 145-161.

Scheibehenne, B., Greifeneder, R., \& Todd, P. M. (2010). Can there ever be too many options? A meta-analytic review of choice overload. Journal of Consumer Research, 37(3), 409-425.

Schwarz, N., \& Clore, G. L. (1983). Mood, misattribution, and judgments of well-being: informative and directive functions of affective states. Journal of Personality and Social Psychology, 45(3), 513.

Sela, A., Berger, J., \& Liu, W. (2009). Variety, vice, and virtue: How assortment size influences option choice. Journal of Consumer Research, 35(6), 941-951.

Sen, S., Gürhan-Canli, Z., \& Morwitz, V. (2001). Withholding consumption: A social dilemma perspective on consumer boycotts. Journal of Consumer Research, 28(3), $399-417$.

Sheppard, J. (2015). Online petitions in Australia: Information, opportunity and gender. Australian Journal of Political Science, 50(3), 480-495.

Shirky, C. (2011). The political power of social media: technology, the public sphere, and political change. Foreign Affairs, 90(1), 28-41.

Skoric, M. M. (2012). What is slack about slacktivism? In M. M. Skoric (Ed.), Methodological and Conceptual Issues in Cyber Activism Research (pp. 77-104). Singapore: Asia Research Institute, National University of Singapore.

Sung, Y., Choi, S. M., Ahn, H., \& Song, Y. A. (2015). Dimensions of luxury brand personality: Scale development and validation. Psychology \& Marketing, 32(1), 121132.

Sykes, G. M., \& Matza, D. (1957). Techniques of neutralization: A theory of delinquency. American Sociological Review, 22(6), 664-670.

Thai, N. T., \& Yuksel, U. (2017). Too many destinations to visit: Tourists' dilemma? Annals of Tourism Research, 62, 38-53. 
Thompson, S. C. G., \& Barton, M. A. (1994). Ecocentric and anthropocentric attitudes toward the environment. Journal of Environmental Psychology, 14(2), 149-157.

Townsend, C., \& Kahn, B. E. (2014). The "visual preference heuristic": The influence of visual versus verbal depiction on assortment processing, perceived variety, and choice overload. Journal of Consumer Research, 40(5), 993-1015.

Tsang, J. A. (2002). Moral rationalization and the integration of situational factors and psychological processes in immoral behavior. Review of General Psychology, 6(1), 2550 .

Tyran, J. R., \& Engelmann, D. (2005). To buy or not to buy? An experimental study of consumer boycotts in retail markets. Economica, 72(285), 1-16.

Wright, S. (2016). 'Success' and online political participation: The case of Downing Street Epetitions. Information, Communication \& Society, 19(6), 843-857.

Xu, J., Jiang, Z., \& Dhar, R. (2013). Mental representation and perceived similarity: How abstract mindset aids choice from large assortments. Journal of Marketing Research, 50(4), 548-559.

Yuksel, U. (2013). Non-participation in anti-consumption: Consumer reluctance to boycott. Journal of Macromarketing, 33(3), 204-16.

Yuksel, U., \& Mryteza, V. (2009). An evaluation of strategic responses to consumer boycotts. Journal of Business Research, 62(2), 248-259.

Zhao, X., Lynch, J. G., \& Chen, Q. (2010). Reconsidering Baron and Kenny: Myths and truths about mediation analysis. Journal of Consumer Research, 37(2), 197-206. 
Table 1. Summary of regression analyses

\begin{tabular}{|c|c|c|c|c|c|c|}
\hline \multirow{3}{*}{$\begin{array}{l}\text { Independent variables and } \\
\text { covariates }\end{array}$} & \multicolumn{6}{|c|}{ Dependent variables } \\
\hline & \multicolumn{3}{|c|}{ Small-agent rationalization (SAR) } & \multicolumn{3}{|c|}{ Signing a petition to boycott } \\
\hline & $B$ & $S E$ & $p$ & $B$ & $S E$ & $p$ \\
\hline Choice-set size & .166 & .067 & .014 & -.318 & .163 & .051 \\
\hline SAR & $\ldots$ & $\ldots$ & $\ldots$ & -.371 & .166 & .025 \\
\hline Regret & $\ldots$ & $\ldots$ & $\ldots$ & .023 & .093 & .808 \\
\hline Choice difficulty & $\ldots$ & $\ldots$ & $\ldots$ & -.138 & .111 & .213 \\
\hline Feeling overwhelmed & $\ldots$ & $\ldots$ & $\ldots$ & .045 & .109 & .678 \\
\hline Perceived success likelihood & -.176 & .051 & .001 & .084 & .121 & .487 \\
\hline Trustworthiness of boycott calls & -.013 & .057 & .826 & .549 & .138 & .000 \\
\hline Equity issue & .115 & .042 & .007 & .131 & .103 & .204 \\
\hline Perceived behavioral control & -.032 & .061 & .605 & .067 & .147 & .650 \\
\hline Brand familiarity & .013 & .058 & .828 & -.011 & .138 & .935 \\
\hline \multirow[t]{2}{*}{ Constant } & 4.319 & .417 & .000 & -2.398 & 1.300 & .065 \\
\hline & \multicolumn{3}{|c|}{$\begin{array}{c}R^{2}=.123 \\
F(6,221)=5.151\end{array}$} & \multicolumn{3}{|c|}{ Nagelkrk $R^{2}=.276$} \\
\hline
\end{tabular}


Figure 1. Mediation Analysis

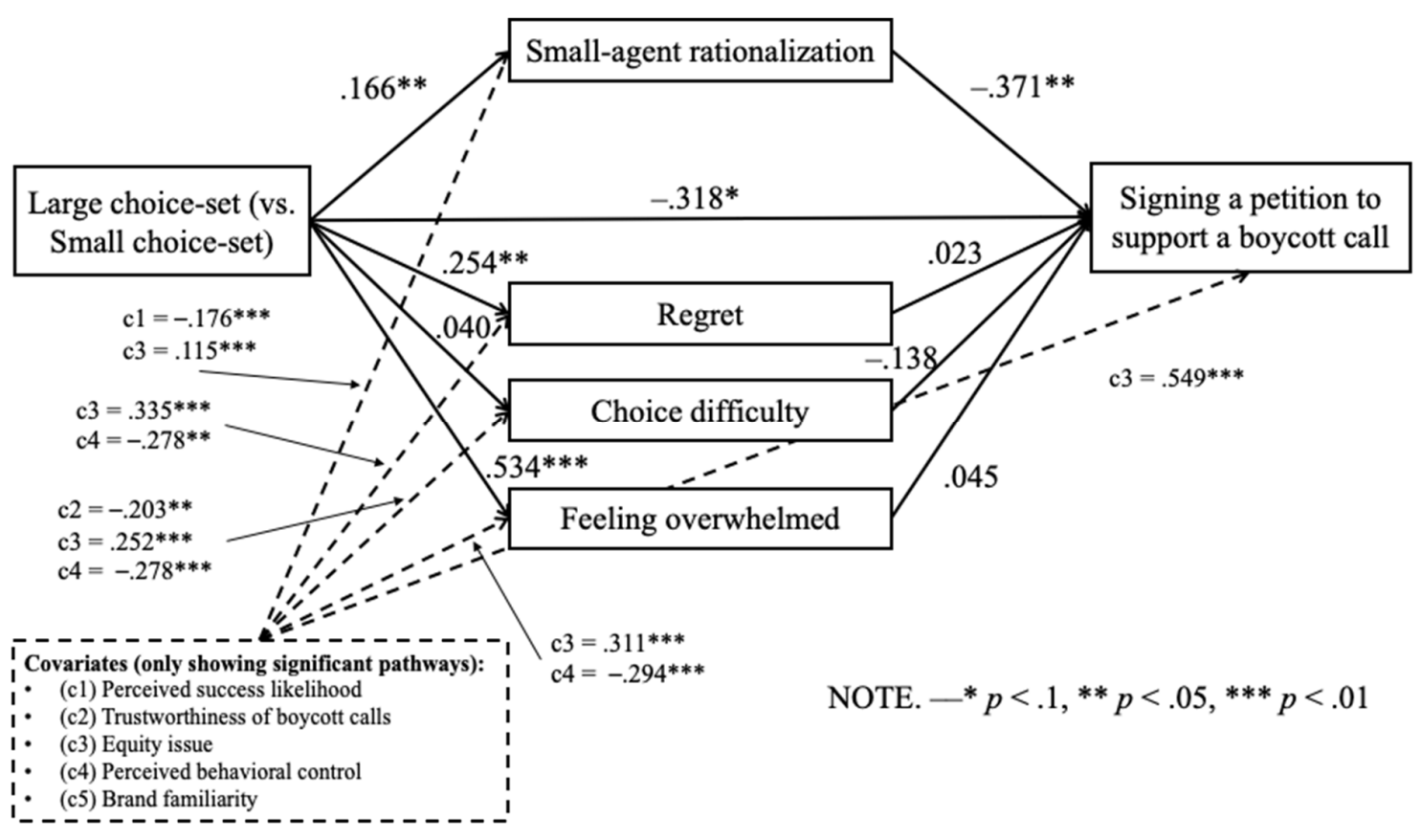


Appendix 1: List of 15 boycott calls

\begin{tabular}{|c|c|}
\hline Adidas & $\begin{array}{l}\text { Category: Animal Rights } \\
\text { Called by: Viva } \\
\text { Boycott call from Viva for using kangaroo skin to make some types of } \\
\text { football boots. Adidas is phasing out the use of kangaroo leather by } 98 \\
\text { percent over } 12 \text { months but will still use small amounts of it so the boycott } \\
\text { continues. }\end{array}$ \\
\hline Ben \& Jerry's & $\begin{array}{l}\text { Category: Political } \\
\text { Called by: BDS Movement } \\
\text { Unilever subsidiary Ben \& Jerry's has been added to the list of companies } \\
\text { boycotted by the BDS movement. The call comes from the brand's long- } \\
\text { standing contractual relationship with an Israeli franchise that } \\
\text { manufactures ice cream in Israel and sells it in Israeli settlements in the } \\
\text { occupied West Bank and East Jerusalem. }\end{array}$ \\
\hline Cadbury & $\begin{array}{l}\text { Category: Political } \\
\text { Called by: Methodist Tax Justice Network, SumOfUS } \\
\text { Campaign say they are boycotting Cadbury "until we see evidence that } \\
\text { Cadbury is paying tax commensurate with their sales in all countries in } \\
\text { which they operate, we will refuse to buy from a company who avoid } \\
\text { making their appropriate contributions to wider society." }\end{array}$ \\
\hline $\begin{array}{l}\text { Driscoll's } \\
\text { (Sakuma } \\
\text { Brand) }\end{array}$ & $\begin{array}{l}\text { Category: Human Rights } \\
\text { Called by: Families United For Justice } \\
\text { Thousands of farm-workers in the US and Mexico have called for a } \\
\text { boycott of Driscoll's which sells Sakuma berries. Thousands of workers } \\
\text { went on strike for two weeks demanding higher wages and legally required } \\
\text { benefits. Independent union Families United for Justice are a representative } \\
\text { of the farm workers and demands Driscoll's to stop selling Sakuma berries. }\end{array}$ \\
\hline Elsevier & $\begin{array}{l}\text { Category: Politics } \\
\text { Called by: The Cost of Knowledge } \\
\text { Academics are boycotting Elsevier's journals due to the "exorbitantly high } \\
\text { prices for subscriptions to individuals and "in the light of these high prices, } \\
\text { the only realistic option for many libraries is to agree to buy very large } \\
\text { bundles, which will include many journals that those libraries do not } \\
\text { actually want. Elsevier thus makes huge profits by exploiting the fact that } \\
\text { some of their journals are essential." }\end{array}$ \\
\hline FedEx & $\begin{array}{l}\text { Category: Human Rights } \\
\text { Called by: Council of Tlingit and Haida Indian Tribes of Alaska } \\
\text { (CTHITA) } \\
\text { CTHITA have called for a boycott of FedEx for as long as they continue to } \\
\text { sponsor the Washington Redskins - who bear a racially offensive name. }\end{array}$ \\
\hline Hermès & $\begin{array}{l}\text { Category: Animal Rights } \\
\text { Called by: PETA } \\
\text { PETA are calling on a boycott of Hermès which sells luxury bags and belts } \\
\text { using skin from reptiles. Alligators and crocodiles are brutally slaughtered } \\
\text { for 'luxury' fashion. }\end{array}$ \\
\hline $\begin{array}{l}\text { Intercontinental } \\
\text { Hotels }\end{array}$ & $\begin{array}{l}\text { Category: Human rights } \\
\text { Called by: freetibet.org }\end{array}$ \\
\hline
\end{tabular}




\begin{tabular}{|c|c|}
\hline & $\begin{array}{l}\text { Free Tibet and other international groups have launched a global boycott } \\
\text { targeting the Intercontinental Hotels Group (IHG), owner of Holiday Inn, } \\
\text { over its plan to open a hotel in Lhasa, the capital of occupied Tibet. }\end{array}$ \\
\hline Kellogg's & $\begin{array}{l}\text { Category: Environment } \\
\text { Called by: Organic Consumers Association } \\
\text { For using sugar from genetically engineered sugar beets in its products. To } \\
\text { see how they rate and for alternatives see Ethical Consumer's free Buyers' } \\
\text { Guide to cereal. }\end{array}$ \\
\hline L'Oreal & $\begin{array}{l}\text { Category: Animal Testing } \\
\text { Called by: Naturewatch } \\
\text { Naturewatch has a long-standing boycott of L'Oreal due to its continued } \\
\text { use of animal testing for cosmetics. The French multinational uses } \\
\text { ingredients that have been tested on animals, despite public statements to } \\
\text { the contrary. It has also been criticized for lobbying against an EU ban on } \\
\text { animal testing for cosmetics. }\end{array}$ \\
\hline Nestlé & $\begin{array}{l}\text { Category: Irresponsible Marketing } \\
\text { Called by: Baby Milk Action } \\
\text { Baby Milk Action has called a boycott of Nestle for its irresponsible } \\
\text { marketing of baby milk formula which infringes the International Code of } \\
\text { Marketing of Breast milk Substitutes. Also criticized for use of Palm Oil } \\
\text { and not labelling GM ingredients. }\end{array}$ \\
\hline Nike & $\begin{array}{l}\text { Category: Animal rights } \\
\text { Called by: Save The Kangaroo } \\
\text { Nike is subject to a boycott call for its use of Kangaroo leather. } \\
\text { Campaigners say that "the methods in which this skin is obtained however } \\
\text { are extremely cruel and involve killing both pregnant mothers and babies } \\
\text { in disturbing manners." }\end{array}$ \\
\hline Staples & $\begin{array}{l}\text { Category: Workers Rights } \\
\text { Called by: American Postal Workers Union } \\
\text { The American Postal Workers Union has called a boycott of Staples } \\
\text { following deal between the company and the post office which saw Staples } \\
\text { open post office branches in its stores. The union argues that these post } \\
\text { offices are staffed by lower paid workers with fewer rights than colleagues } \\
\text { doing the same jobs in traditional post offices. }\end{array}$ \\
\hline Starbucks & $\begin{array}{l}\text { Category: Worker Rights } \\
\text { Called by: Organic Consumer's Association } \\
\text { Starbucks is under a boycott call from the US Organic Consumer's } \\
\text { Association over its treatment of Ethiopian coffee farmers. Also heavily } \\
\text { criticized by Ethical Consumer over corporate tax avoidance. }\end{array}$ \\
\hline Wendy's & $\begin{array}{l}\text { Category: Human Rights } \\
\text { Called by: Coalition of Immokalee Workers } \\
\text { The boycott was called after Wendy's refused to join the Fair Food } \\
\text { Program (FFP). The FFO is a social responsibility program that addresses } \\
\text { decades-old farm labour abuses. All Wendy's major competitors such as } \\
\text { McDonald's, Burger King, Subway and Taco Bell have signed up. Those } \\
\text { that sign up agree to purchase exclusively from suppliers meeting the code } \\
\text { of conduct including a zero-tolerance policy for slavery and sexual } \\
\text { harassment. }\end{array}$ \\
\hline
\end{tabular}


Appendix 2: List of 15 brands and why they should be boycotted (Study 2)

\begin{tabular}{|l|l|}
\hline Adidas & Boycott Adidas for using kangaroo skin to make football boots. \\
\hline Ben \& Jerry's & $\begin{array}{l}\text { Boycott Ben \& Jerry's for the brand's long-standing contractual relationship } \\
\text { with an Israeli franchise that manufactures ice cream in Israel and sells it in } \\
\text { Israel settlements in the occupied West Bank and East Jerusalem. }\end{array}$ \\
\hline Cadbury & Boycott Cadbury for tax avoidance. \\
\hline $\begin{array}{l}\text { Driscoll's } \\
\text { Bakuma }\end{array}$ & Boycott Driscoll for exploiting their workers. \\
\hline Elsevier & $\begin{array}{l}\text { Boycott Elsevier for exorbitantly high prices for subscriptions to academic } \\
\text { journals. }\end{array}$ \\
\hline FedEx & $\begin{array}{l}\text { Boycott FedEx for sponsoring the Washington Redskins who bear a racially } \\
\text { offensive name. }\end{array}$ \\
\hline Hermès & Boycott Hermes for using skin from reptiles. \\
\hline $\begin{array}{l}\text { Intercontinental } \\
\text { Hotels }\end{array}$ & $\begin{array}{l}\text { Boycott Intercontinental Hotels Group for opening a hotel in Lhasa, the capital } \\
\text { of occupied Tibet. }\end{array}$ \\
\hline Kellogg's & $\begin{array}{l}\text { Boycott Kellogg's for using sugar from genetically engineered sugar beets in its } \\
\text { products. }\end{array}$ \\
\hline L'Oreal & Boycott L'Oreal for its continued use of animal testing for cosmetics. \\
\hline Nestlé & $\begin{array}{l}\text { Boycott Nestle for its irresponsible marketing of baby milk formula which } \\
\text { infringes the International Code of Marketing of Breast Milk Substitutes. }\end{array}$ \\
\hline Nike & Boycott Nike for its use of kangaroo leather. \\
\hline Staples & $\begin{array}{l}\text { Boycott Staples for opening post office branches in its stores with lower paid } \\
\text { workers compared with colleagues doing the same jobs in traditional post } \\
\text { offices. }\end{array}$ \\
\hline Boycott Starbucks for its poor treatment of Ethiopian coffee farmers. \\
\hline Starbucks & $\begin{array}{l}\text { Boycott Wendy for refusing to join the Fair Food Program which addresses } \\
\text { decades-old farm labor abuses. }\end{array}$ \\
\hline Wendy's & \\
\hline
\end{tabular}

